Francesco G. Barsacchi

\title{
KBo 20.64: A Hittite Invocation Ritual Mentioning the Thunder
}

DOI 10.1515/aofo-2016-0002

\begin{abstract}
The short Hittite fragment 1086/c=KBo 20.64, currently listed among the texts related to the thunder festival under the number 631 of the Catalogue des Textes Hittites, presents some features that clearly distinguish it from the other documents collected under the same catalogue entry. It represents in my opinion what is left of an invocation ritual directed to a deity, probably to be identified with a hypostasis of the Stormgod, as the presence of the word tetheššar, "thunder", in the colophon seems to suggest. The text must therefore be collocated elsewhere, and I propose, in consideration of its content and structure, to place it either among the fragments of mugawar rites for the Storm-god under CTH 332 or, more generally, under CTH 459 (Fragments of mugawar). This paper presents for the first time a transcription, translation and commentary of the fragment. Interesting elements emerge from a comparison with KBo 30.119, another fragmentary tablet, erroneously classified among the fragments of festivals under CTH 670, where a similar invocation ritual seems to be described.
\end{abstract}

Keywords: Hittite, religion, cult, invocation rituals, thunder, Storm-god

\section{Introduction}

Among the Hittite texts and fragments currently filed under CTH 631, one clearly stands out for its content as well as for its structure. While the other documents of the corpus can be recognized as Hittite festival descriptions ${ }^{1}$ and are labeled with the sumerogram EZEN $_{4}$, the fragment 1086/c, published by H. Otten as KBo 20.64, shows the peculiar features of the so called "invocation rituals".

In this paper, I will provide a transcription, a translation and a philological commentary of the lines preserved. Unfortunately, most of the text is lost, and the broken conditions of what is left prevent us from identifying correctly the development of the ritual, as well as its purpose and the main actors involved.

\section{The Text}

The fragment, most likely part of a single-column tablet, is currently classified as junghethitisch in the online Hethitologie Portal, ${ }^{2}$ but it should be dated to an advanced Middle Script phase, ${ }^{3}$ IIb or IIc according to Starke's classification ${ }^{4}$, as shown by the presence of sign shapes such as E, still with the single broken vertical, AH and URU, as well as by the large use of logographic instead of phonetic writings. DA and IT show no extended lower horizontal, generally considered a Middle Hittite feature, which confirms the difficulty in

1 See, e.g., the $\mathrm{OH}$ festival KBo 17.74 first published by Neu (1970). The whole corpus has now been edited in my PhD dissertation Le cerimonie ittite del tuono. Edizione critica di CTH 630 e 631, which was discussed in April 2014 at the University of Florence and is currently under revision for publication.

2 S. Košak, hethiter.net/: hetkonk (v. 1.94).

3 A MS date is also suggested by CHD Š 396a (MS?).

4 Starke (1985: 22-27).

Francesco G. Barsacchi, Università degli Studi di Firenze, Dipartimento di Storia, Archeologia, Geografia, Arti e Spettacolo (SAGAS), Via San Gallo 10, 50129 Firenze, E-Mail: francescobarsacchi@hotmail.com 
the use of this sign as a reliable dating element, as recently underlined by several scholars. ${ }^{5}$ Also notable are the signs ŠA and TA with the inscribed vertical clearly below the top horizontal, but these elements also can hardly be used as a distinctive feature, given the variability with which the internal verticals, especially in the signs TA and GA, are documented from the $\mathrm{OH}$ period. ${ }^{6}$

\section{Transcription}

KBo 20.64

Obv.

\begin{tabular}{|c|c|}
\hline 1 & ]-na? [ \\
\hline 2 & ] na-an pár-šs[i-ia] \\
\hline 3 & ] x $k u$-in ${ }^{\mathrm{NINDA}}$ ta-[kar-mu-un] \\
\hline 4 & ] $\mathrm{xx}$ \\
\hline 5 & $t] a-m a-i{ }^{\mathrm{GI} I \check{B}} \mathrm{BANŠUR}$ AD.KID $d a-a-{ }^{\ulcorner} i^{\top}$ \\
\hline 6 & {$\left[\right.$ še-er-ma-aš-ša (?)]-an $1^{\mathrm{NINDA}} w a-{ }^{\ulcorner} g e^{\urcorner}-e s ̌-s ̌ a r ~ d a-a-i ~ n a-a t P A-N I^{\mathrm{GIS}}{ }_{\mathrm{AB}} d a-{ }^{-} a-i^{\urcorner}$} \\
\hline 7 & $\left.A-N A \mathrm{~d}_{\mathrm{IM}}(?)\right] S_{A}-M E-E$ ši-pa-an-du-it KŨ.BABBAR GEŠTIN-it ši-pa-an-ti \\
\hline 8 & 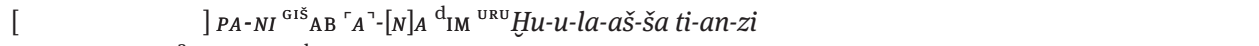 \\
\hline 9 & 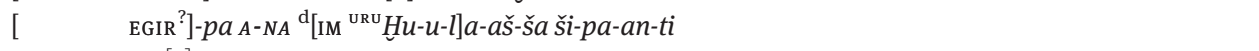 \\
\hline 10 & {$\left[{ }^{\mathrm{UZU}}{ }^{\mathrm{NIG}} \cdot \mathrm{GIG}^{\mathrm{HI}}\right]^{{ }^{\mathrm{A}}{ }^{7} \mathrm{UZU}} \mathrm{S}\left[\hat{\AA}^{\mathrm{HI} \cdot \mathrm{A}} \mathrm{IZI}-i\right] t z a-n u-a n-z i$} \\
\hline 11 & 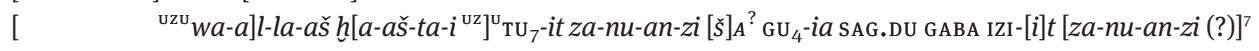 \\
\hline
\end{tabular}

\begin{tabular}{|c|c|c|}
\hline 12 & {[} & $\left.\check{S}_{A}\right] 1 / 2 \check{S}_{A}-A-T I 11^{?} \mathrm{NINDA}^{\mathrm{K} U} \breve{S}_{7} 1 / 2 U P-N I$ BA.BA.ZA ${ }^{8}$ \\
\hline 13 & {[} & 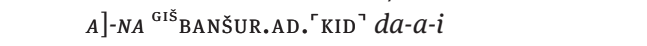 \\
\hline 14 & {[} & ]'SAG.DU $\left.{ }^{\mathrm{UZU}} \mathrm{GABA}^{\urcorner}-i a^{\mathrm{r}} \mathrm{IZI}^{?}\right\urcorner-i t^{9}$ \\
\hline 15 & {$[z a-n u-a n-z i$} & ] $\mathrm{GE}_{6} \mathrm{SAG} \cdot \mathrm{DU} \mathrm{GU}{ }_{4}^{10}$ \\
\hline 16 & {[} & ] $\mathrm{x}$ \\
\hline 17 & {[} & 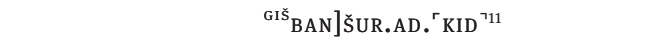 \\
\hline 18 & {[} & ]x \\
\hline 19 & {[} & $-n] a-a n$ \\
\hline 20 & {[} & $-r] i$ \\
\hline 21 & {[} & ]$^{r} P A^{7}-N I X\left[{ }^{12}\right.$ \\
\hline \multicolumn{3}{|c|}{ Rev. } \\
\hline$x+1$ & {[} & \\
\hline $2^{\prime}$ & {[} & ] İ.DÙG.GA-i $\left[a^{?}\right.$ \\
\hline $3^{\prime}$ & {[} & $\check{s}]$ e-er LÅL $[l a-a]-h u^{\prime}-i n\left[a^{?} ?\right.$ \\
\hline
\end{tabular}

\begin{tabular}{|c|c|}
\hline $4^{\prime}$ & $h u]$-it-ti-ia-z[ix x (x)] x-ma-wa-ra-aš $I \check{I s}-T U^{\urcorner}[$ \\
\hline $5^{\prime}$ & ]x-an Gìn-i[t x x x] x e-ez-za-an GIš-ru ha-ah-hal \\
\hline $6^{\prime}$ & ]-a-aš-[x x X X X] İ.NUN LÃL KASKAL- $a \check{s}$ \\
\hline $7^{\prime}$ & šu-u]n-na-i \\
\hline
\end{tabular}

\begin{tabular}{|c|c|c|}
\hline $8^{\prime}$ & I & $\mathrm{EG}]_{\mathrm{IR}}-a[n \times \mathrm{x} \times \mathrm{x}] \mathrm{x}-n u-m a-a n-z i p a-i z-z i$ \\
\hline $9^{\prime}$ & [ & ]X NINDA.[GUR $4 \cdot$ RA (?) š] $]_{A} 1 / 2$ UP-NI pár-ši-ia \\
\hline $10^{\prime}$ & {[} & $-i] s^{?} d[a-r i-i] a-n u-z i$ nu-za NINDA.GUR4.RA \\
\hline $11^{\prime}$ & [ & ]-zi ${ }^{\ulcorner} n a^{\urcorner}-a s ̌-t a$ URU-ri še-er \\
\hline
\end{tabular}

5 See Weeden (2004: 47), with further literature. Cf. Rüster / Wilhelm (2012: 65-67).

6 Cf. Weeden (2004: 45, and especially n. 198, 206).

7 From $[\check{s}]_{A}$ ? onwards, the line continues on the edge and on the reverse of the tablet. This line and the following one are written on erasure.

8 From $\check{s} A$ written on the edge. The sign ZA is visible on the obverse.

$9{ }^{\mathrm{r}} \mathrm{IZI}^{?}{ }^{?}$-it written on the edge.

10 Written on the edge.

11 Written on the edge.

12 Written on the edge. 


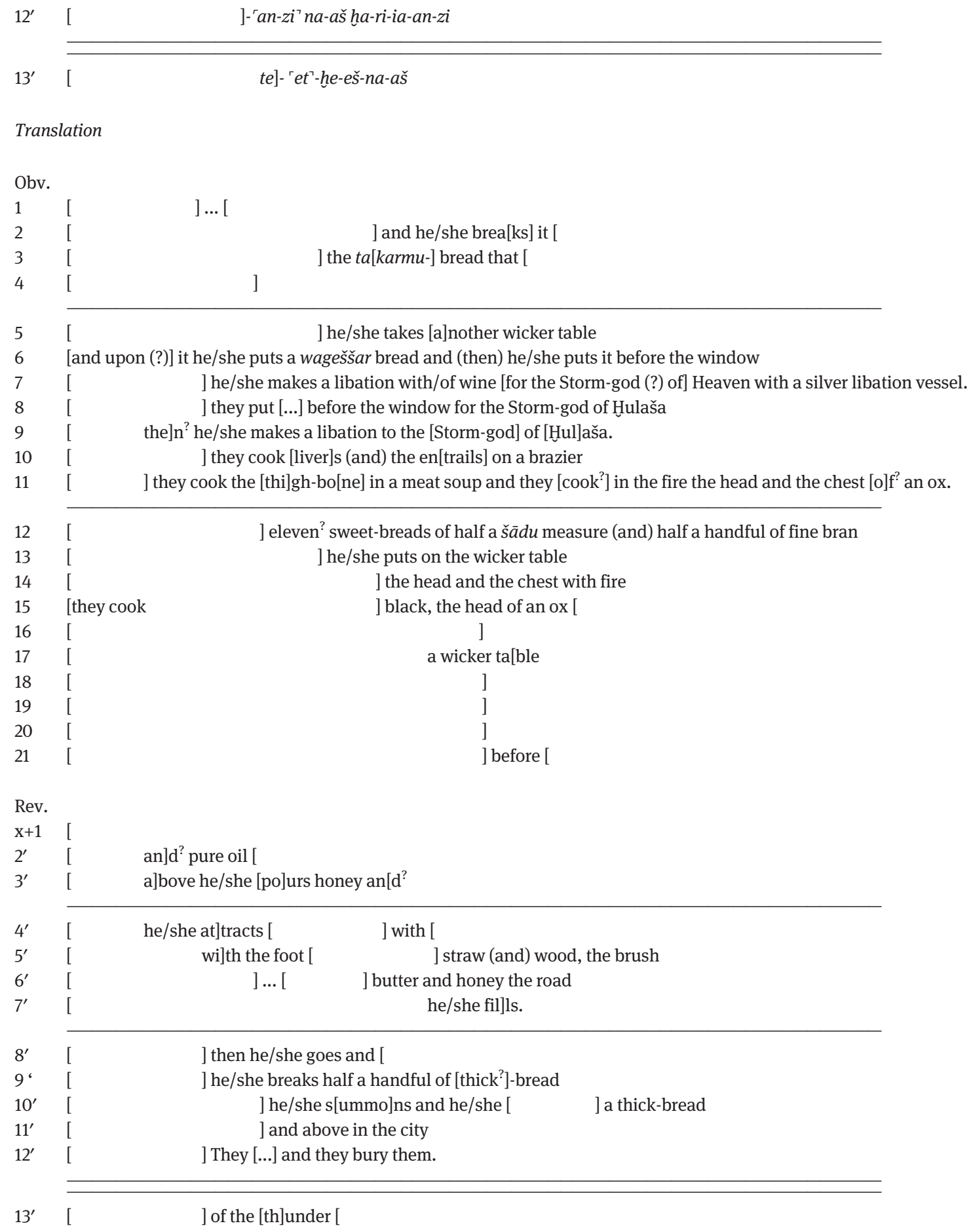

\section{Philological commentary}

Obv. 3: Otten in his autograph reads the first sign after the break at the beginning of the line as LU, which does not seem likely. Considering that the presence of a sign I can be excluded by the comparison with the sign as it appears in the following paragraph, I prefer to keep the reading uncertain.

Obv. 6: The proposed restoration [še-er-ma-aš-ša]-an is suggested to me by the comparison with KBo 17.75 obv. i 38, another text filed under CTH 631 which describes the action, performed this time by a palace attendant, of putting the NINDA.ÉRIN ${ }^{\mathrm{ME}}$

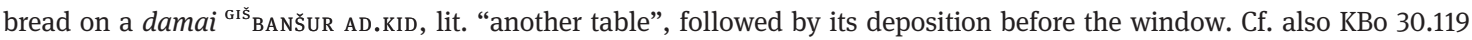
obv. ${ }^{\mathrm{x}+1}$ (CTH 670). 
Obv. 7: The integration [... ${ }_{\text {IM }}$, although hypothetical, seems to be confirmed by the occurrence of the Storm-god of Heaven in the parallel text KBo 30.119 obv. $17{ }^{\prime} \cdot{ }^{13}$ Cf. CHD Š $396 a$, where the alternative reading $\left[{ }^{d} \mathrm{UTU} /{ }^{\mathrm{d}} \mathrm{U}\right.$ ] is given.

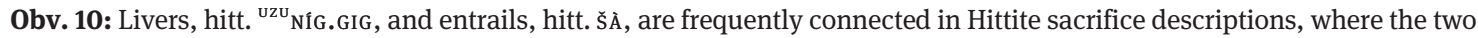
meat cuts are generally cooked together on the happina- brazier. ${ }^{14}$ The reading $\left[{ }^{\mathrm{UZU}} \mathrm{NIG}^{\mathrm{G}} \cdot \mathrm{GIG}^{\mathrm{HI}}\right]^{\cdot{ }^{\circ} \mathrm{A}^{\top}}$ corresponds to the vertical wedge partially visible after the break at the beginning of the line. Cf. also KBo $30.119 \mathrm{obv} .5^{\prime} .{ }^{15}$

Obv. 11: The term walla-/uwalla-, very likely referring to the thigh, is discussed in Torri (2003: 88), with further literature. Cf. Fuscagni (2007: 208).

Obv. 12: The reading of this line is severely affected by an erasure. A. Hagenbuchner-Dresel (Hagenbuchner-Dresel 2002: 158) ignores the little Winkelhaken visible on the photo immediately before the vertical wedge that precedes NINDA, and transcribes hypothetically $1^{\text {!? }}$. After the collation on the photo I prefer the reading 11 , with a certain caution considering that Otten's autograph, based on the original fragment, shows in this place a horizontal wedge immediately before the vertical. The sign NINDA poses some problems as well, since a diagonal wedge, not signaled on the hand-copy, seems to be traced next to the lower vertical wedge of this sign. This could possibly be understood as an overwritten sign, considering that the line is partly erased.

Obv. 14: The vertical wedge before it could well correspond to the end of the sign IZI. The presence of some horizontal wedges immediately before is deducible from the observation of the photograph, as correctly reported in the autograph.

Rev. 3': The distance between the sign I and what follows supports the integration $[l a-a-h] u-i$, present $3^{\text {rd }}$ person singular of lah, lahu-, lahhuwai, "to pour”. This hypothesis seems to be supported by the occurrence: 'še $e^{-}$-er[ / [...] I I.Nun la-a-hu-[ in KBo 30.119 obv. ${ }^{?}, 12^{\prime}-13^{\prime}$.

Rev. 4': The syntactic chain -mawaraš, which has to be interpreted as formed by the conjunction ma + direct speech particle $w a r+$ nominative $3^{\text {rd }}$ person singular of the enclitic personal pronoun common gender -aš, indicates that we are dealing with a direct speech, performed by the officiant of the rite. The preceding signs, of which only two Winkelhaken are visible, might well be interpreted as NAM.

Rev. 5': For the terms ezzan and hahhhal, see HW² II E 141; HW' III H 3-4. Cf. also the considerations by H.G. Güterbock (Güterbock 1952: 36-37).

Rev. 10': The first sign after the break at the beginning of the line is not easily recognizable. While for this a reading IŠ cannot be excluded, the reading DA for the following sign seems certain, in consideration of the three horizontal wedges, clearly observable both in the photo and in the autograph. In view of this, the reading $d[a-r i-i] a-n u-z i$ seems to me most plausible. The use of the verb, present $3^{\text {rd }}$ person singular of the factitive form of dariya-, "to call", "to summon" (cf. HEG T, D/2 171172), is consistent with the interpretation of the text as an invocation ritual and would fit perfectly in the context of the passage ${ }^{16}$

Rev. 11': At the beginning of the line one would expect the presence of a $3^{\text {rd }}$ person verb (singular or plural) dependent on the same subject as the preceding verb and introduced by the chain $n u=z a$.

Rev. 12': The verb hariya-, "to bury" is used, according to HW' III H 277-278, in ritual contexts to express the action of burying some materials used during the rites or, in a figurative sense, to indicate a negative action, physical or symbolical, carried out against people or things.

Rev. 13': The colophon of the text, after a double paragraph line, is only partially preserved. The reading [te]-'et $t^{\top}-h e-e s ̌-n a-a s ̌$ is to my knowledge the only possible one in considerations of the signs.

After this line, one can see on the tablet a few signs belonging to the lines $11^{\prime}$ and $12^{\prime}$ of the obverse.

\section{Discussion}

The incipit of the text is unfortunately lost. The first preserved section of the obverse clearly describes the preparation of the materia magica to be used during the rite. Although in broken context, it is possible to understand that bread breakings and libations before a window are carried out for the Storm-god of Heaven (if the restoration in line 7, based on the occurrence of this deity in the parallel text KBo 30.119, is correct) and for the Storm-god of Hulaša/Hulašiya. Ritual actions performed before a window constitute a typical praxis of Hittite thunder festivals. ${ }^{17}$ Similar passages can be found in KBo 20.61+ obv. ii $27-29$, KBo 17.75 obv. i 2931, VS NF 12.10 obv. i $21^{\prime}-24^{\prime}$.

13 For the transcription and translation of the text, see below.

14 I refer here to the examples of sacrifice descriptions collected by Mouton (2004: 67-92).

15 See the text edition below.

16 On the interpretation of the term, however, see also the critical considerations by Güterbock (1957: 358-359).

17 See Wilhelm (1995: 383-388). 
The occurrence of the Storm-god of Hulaša is particularly interesting. This local hypostasis of the main god of the Hittite pantheon is mentioned in the small fragment KBo 25.191, generally ascribed, perhaps improperly, to CTH 630, The Festival of the Moon and the Thunder. ${ }^{18}$ During the festival for Ištar of Šamuha CTH 712, the god receives offerings in a divine list documented in KUB 47.64 and in KUB 27.1, where he is mentioned immediately after the Storm-god of Kuliwišna. In the inventory of Storm-gods KUB 44.1, the celebration of a monthly festival, EzEN ${ }_{4}$ ITU, for this deity, is also attested, from line obv. $6^{\prime}$ onwards. The text is organized in sections dealing with different festivals, or different days of the same festival, separated by single or double paragraph lines. The storm-god of Hulaša is attested several times, respectively in connec-

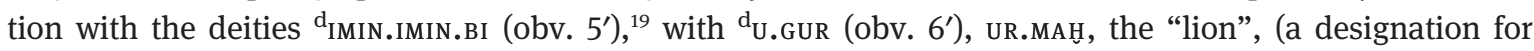
Wašezzili? Cf. KUB 8.41(+) obv. $6^{\prime}=$ CTH 733), the god KAL ${ }^{20}$ and the goddess Maliya. ${ }^{21}$

In the treaty between Šuppiluliuma and Hukkana CTH 42, the Storm-god of Hulaša occurs in the group of divine witnesses after the Storm-gods of Uda, Kizzuwatna, Pitijarik, Šamuha, Šarišša, Hurma, Lihzzina, [...], [Arin]na?, which suggests, according to A. Goetze, ${ }^{22}$ a southeastern localization for this town. The city of Hulaša is in fact documented as a center located in the region of Kizzuwatna in the text KUB 40.2 (CTH 641.1), a very peculiar document concerning the renewal, made by a Hittite king (to be identified with Šuppluliuma $\mathrm{I}^{23}$ ), of a donation act originally issued by Šunaššura and his predecessor Talzu in favor of a religious center, probably to be identified with a temple of Išhara, and the re-organization of the tribute due to the sanctuary and its clergy. ${ }^{24}$ The villages and estates mentioned in the text clearly belong to the geographical area formerly under the direct administration of Kizzuwatna, but at the moment of the creation of the document under Hittite control (at least formally). In line obv. 30 of the text the city Hulaša is explicitly indicated as "close to Tarša" (classical Tarsus): ${ }^{\mathrm{URU}} h \mathrm{hu}$-u-la-aš-ša ${ }^{\mathrm{URU}}$ tar-ša ma-a-ni-in-ku-wa-an. ${ }^{25}$

A single element in itself cannot be used to ascertain the provenance of a specific ritual tradition. The mentioning in KBo 20.64 of the Storm-god of Hulaša and of other deities connected with this city seems indeed to indicate a possible southern provenance for the text, which is certainly not enough to indicate that the ritual described is actually Kizzuwatnean. ${ }^{26}$

The reverse of the tablet describes the proper invocation rite, centered on the creation of a magic path, typically made of precious things and desirable foods, intended to attract the god or the gods to which the rite is addressed, and to invite him (or them) to come back to the land of Hatti. The use of the logogram Gìr, "foot", in the instrumental case in rev. $5^{\prime}$ represents a topos of Hittite invocations ${ }^{27}$ and could be explained in the sense that the deity invoked is invited to walk on the path set out, thus avoiding treading with the foot on rough terrain..$^{28}$ The presence of direct speech, which can be identified in line rev. $4^{\prime}$, is probably to be understood as the invocation itself, performed by the practitioner, whose name and title are unfortunately lost. This idea is supported by the probable presence of a verb like dariya- in rev. 10'. The technical verb

18 The attribution of KBo 25.191 to CTH 630, suggested also by Klinger (1996: 167), is based in my opinion on two main considerations: the presence of deities such as Zuliya and Wašumma seems to indicate a Hattian influence which can actually be traced in the festival of the Moon and the Thunder. See Laroche (1973: 89). Zuliya (but not Wašumma) is in fact attested in the fragment KBo $20.70+$ KBo 21.88 obv. ii $x+1$, generally ascribed to CTH 630. The other element upon which the attribution of KBo 25.191 to CTH 630 is based, i.e. the presence of the storm-god of Hulaša, certainly connects the text with KBo 20.64, but must be rejected in light of the interpretation of the latter as an invocation ritual, and its consequent re-collocation under a different CTH number.

19 On which see Polvani, (2005: 181-194)

20 I follow Hawkins (2005: 291), who associates the logogram with the deity represented in Hittite glyptic in association with a stag, rejecting the alternative reading Lamma, which would reproduce the Mesopotamian name of the protective deity lamassu. Cf. also Laroche (1980-1983: 455-459) and, more recently, Archi (forthcoming).

21 On the goddess Maliya, see below.

22 Goetze (1940: 70).

23 See also Freu (1992: 48).

24 Edited by A. Chrzanowska (ed.), hethiter.net/: CTH 641 .1 (INTR 2011-08-30).

25 For the geography of the region see in particular Forlanini (1988: 129-169).

26 See the considerations by Miller (2004: 441-469).

27 Cf. HW $^{2}$ III H 3-4.

28 See below about the (possible) presence of this theme in KBo 30.119. 
huittiya-, literally "to draw", in rev. 4', and the substantive KaSKAL, "path" in rev. 6', as well as the mention of scented and agreeable substances like pure oil, İ.DÙG.GA (rev. 2'), honey, LÀL (rev. 3', 6') and butter, İ.NuN (rev. $6^{\prime}$ ) strongly supports the identification of the composition with an invocation ritual.

The rite seems to end with the elimination of the ritual remains by burial, a praxis with a clear cathartic function which, to my knowledge, is not documented in invocation rituals, while well attested in other contexts. In the ritual KUB 58.83 ii 14-15 (CTH 418), performed when an enemy commits a crime against the royal couple, ${ }^{29}$ what is left of the offerings is buried in an "untouched place": ${ }^{(14)}[n] a$-aš-ta ku-up-tar A-NA ${ }^{\mathrm{DUG}}{ }^{\mathrm{U} T U L}$ TUR an-da la-hu-wa-an-zi / ${ }^{(15)}[$ [na-a]n dam-me-li pé-di ha-ri-ia-an-zi (...), "they pour the remains of the offerings in a small keg [and] bury [i]t in an intact place". In purification rituals the burial responds to the need to remove impurities ${ }^{30}$ by sending them to the Netherworld through pits. ${ }^{31}$ In ritual KBo 17.78 (CTH 652), performed when someone is hit by lightning and dies, the same verb hariya-is used to indicate the burial of the deceased, contaminated by the god's anger, carried out by the "man of the Storm-god". ${ }^{32}$

In Hittite invocation rituals, depositional practices connected with the use of pits are attested as well, but with a different religious significance. In the Ritual of Drawing Paths KUB 15.31 (CTH 484), ${ }^{33}$ performed for the DINGIR.MAH deities and the ${ }^{\mathrm{d}} \mathrm{Gulšeš,} \mathrm{offerings} \mathrm{and} \mathrm{symbolic} \mathrm{objects} \mathrm{are} \mathrm{laid} \mathrm{in} \mathrm{nine} \mathrm{pits} \mathrm{dug} \mathrm{into} \mathrm{the} \mathrm{ground,}$ whose location has been determined by means of an oracular investigation, in order to attract the chthonic deities. This use of pits does not seem to fit the context described in KBo 20.64, where the burial takes place at the end of the ritual, immediately before the double paragraph line which closes the text.

Another consideration strengthens the idea that the final burial described in KBo 20.64 has to be interpreted as a ritual deposition with a cathartic meaning. In the ritual of Alli CTH 402, ${ }^{34}$ performed to prevent the negative effects of black magic, clay figurines and other substances such as threads and cloths are buried after being charged with impurities, thus reaching the Underworld. At the end of the ritual, the officiant and the other participants go to the city (KUB 24.9 rev. iv 31: (...) na-at an-da-an UR[U-i]a ú-it), where the final purifications take place. The same can be observed at the end of the flood ritual carried out by Tunnawi CTH 409, concerning the disposal of impurities, where the "old woman", at the end of the ceremony: (...) ša-ra-a URU-ia p[é-en-na]-i, "drives up to the city” (KUB 7.53+ rev. iv 42). Hittite purification rituals are performed outside the space of the city, in an uninhabited location (the "untouched place" of KUB 58.83) where the impurities can be disposed of without danger for the community. ${ }^{35}$ In KBo 20.64 rev. 11', the indication URU-ri še-er [...] could be interpreted in this light. It has to be noted that the postposition šer has originally a locative and not an allative meaning, but here it could well be intended as expressing a location as the result of a movement, ${ }^{36}$ probably indicated by the verb lost in the break at the beginning of the line, of which only the final $-z i$ can be read. The mentioning of the city in this context could thus be seen as an indication that the ritual takes place outside the town. At the end of the ceremony, the officiant goes back to the city, while the other participants (cf. the plural ending -anzi in rev. 12') dispose of the ritual remains by burying them. If this hypothesis is correct, this indication could support the identification of the final operation described in KBo 20.64 as a purification rite. If we assume that the invocation ritual in question is directed towards an angry god who has left his place (see below), it could well be that the burial of some offerings, possibly preceded by a burning rite, ${ }^{37}$ has to be understood as a symbolic elimination of the impurity caused by the absence of the god, and the consequent disruption of the natural order.

29 Popko (1991: 44-53).

30 On the Hittite concept of 'purity', see the interesting considerations of Hutter (2013: 159-174), with further literature.

31 On the use of pits in Hittite ritual practice, see Collins (2002: 224-241). Cf. also Strauß (2006: 49-56).

32 Cf. Ünal (1998: 73-75).

33 Edited by Haas / Wilhelm (1974:143-181) and, more recently, by Fuscagni (ed.), hethiter.net/: CTH 484 (INTR 2013-02-18). See also Hoffner Jr. (1967: 390); Collins (2002: 227).

34 Published by Jakob-Rost (1972). See also Mouton (2012; 2013).

35 On the disposal of impurity in Hittite tradition see, in general, Wright (1987: 261-271).

36 This idea is further confirmed by the presence of the particle - ašta. Cf. Melchert / Hoffner Jr. (2008: 383).

37 Cf. below: KBo 30.119 rev. 22'-24'. 


\section{KBo 30.119}

Looking for texts with a similar content, I was struck by the affinities between KBo 20.64 and KBo 30.119, another manuscript dated to the imperial period, currently listed among the Hittite fragments of festivals in CTH $670 .{ }^{38}$ In my opinion, both documents share so strong similarities that they can be analyzed as parallels, even though the exact relationship between the two texts is hard to determine. Although very badly preserved, KBo 30.119 shows the same structure, and probably describes the same rites, as KBo 20.64. Both texts come from Büyükkale, but apparently from different storing places: KBo 20.64 comes from Building A, whereas KBo 30.119 was found above the west wall of Building G, in a disturbed context. ${ }^{39}$ An original provenance of this tablet from Building A cannot be excluded with certainty, given the proximity of the two places.

Regrettably, also in this case only a very small portion of the tablet is preserved, and large parts of the text are completely lost. Only a few words can therefore be confidently restored.

\section{Transcription}

KBo 30.119
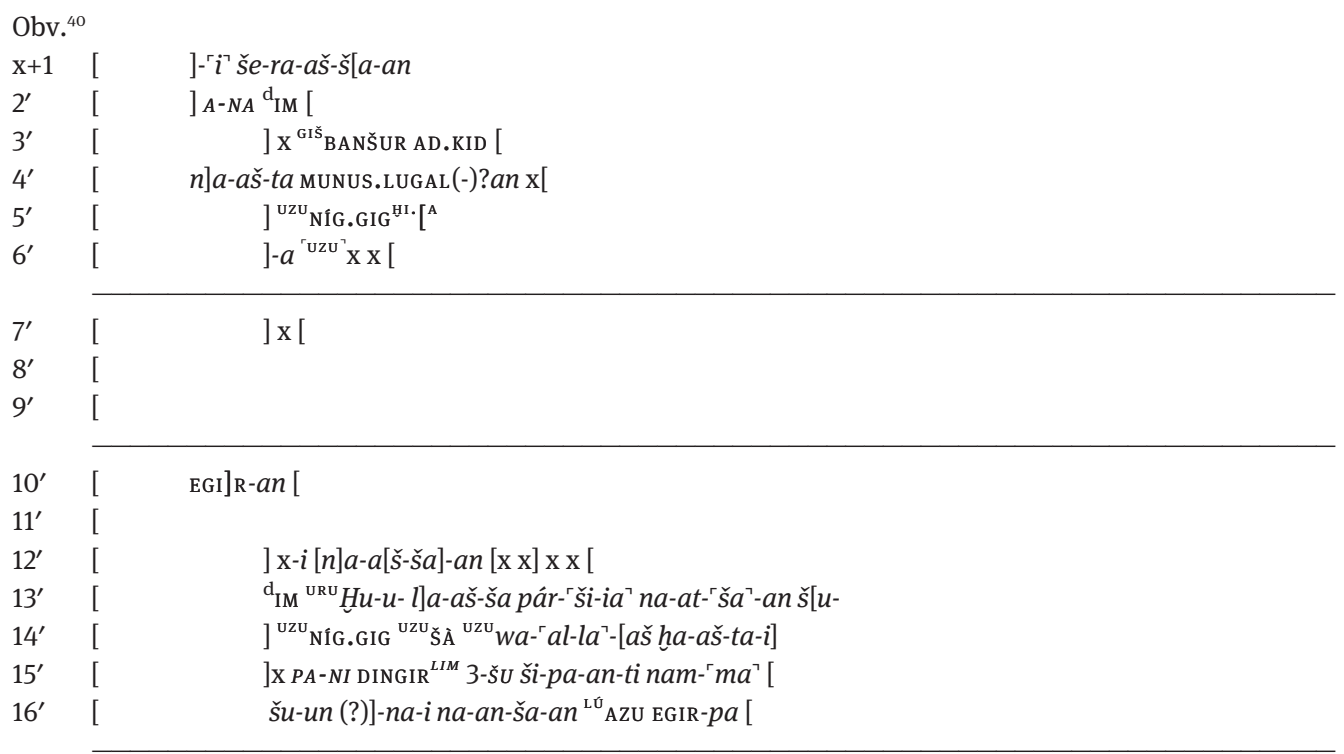

\begin{tabular}{|c|c|}
\hline [ & $\left.\mathrm{d}_{\mathrm{I}}\right]_{M} \check{S}_{A}-M E-E B I-I B-R U$ GUŠKIN GEŠTIN $-i[t$ \\
\hline[ & ] 'кŪ'. BABBAR $l a-a-h u-i$ nu a-NA MUNUS.LUGAL $a-k[u-a n-n a$ \\
\hline$[p a-a-i(?)$ & GU]ŠKIN GEŠTIN-it pa-an-ku-it 2-šU [ \\
\hline[ & $A-N]_{A}{ }^{\text {Giš BANŠUR AD.KID } d a-a-i[}$ \\
\hline[ & $\left.{ }^{\mathrm{d}} M\right] a-a-l i-i a{ }^{\mathrm{d}}$ UTU e-ku-zi n[am-ma \\
\hline[ & EG]IR-pa A-NA ${ }^{\mathrm{I}} \mathrm{IM} d a-{ }^{-} a^{\urcorner}-i$ \\
\hline [ & $\left.{ }^{\mathrm{LU}} \mathrm{SA}\right]_{\mathrm{GI}}{ }^{?} A-N A{ }_{\mathrm{IM}}^{\mathrm{d}}{ }^{\mathrm{C} U \mathrm{UU}}{ }^{\prime}[$ \\
\hline[ & $a r]-h a d a-a-{ }^{\ulcorner} i^{\urcorner} n a-a n(-)[$ \\
\hline[ & 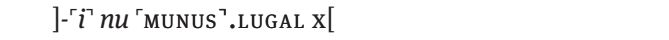 \\
\hline [ & ]$-z a^{?}(-)[\mathrm{x}(\mathrm{x})] \mathrm{x}[$ \\
\hline[ & ] xxx[ \\
\hline[ & ] x x [ \\
\hline
\end{tabular}

38 The text was already transcribed by Groddek (2002: 167-168).

39 S. Košak, hethiter.net/: hetkonk (v. 1.94).

40 As compared with the autograph, the obverse and the reverse of the tablet are inverted, in consideration of KBo 20.64, where a similar sequence of actions is described. 
Rev.

$\mathrm{x}+1 \quad[\mathrm{x} \mathrm{x}(\mathrm{x})] \mathrm{x} \mathrm{x}$

$2^{\prime} \quad[\mathrm{x} \mathrm{x}(\mathrm{x})]-{ }^{r} a^{\urcorner}-a s^{\prime}-n a-\mathrm{x}[$

$3^{\prime} \quad[\mathrm{x} \mathrm{x}(\mathrm{x})]^{\mathrm{d}} \mathrm{IM}{ }^{\mathrm{URU}}[$

$4^{\prime} \quad[\mathrm{x} \mathrm{x}(\mathrm{x}) \text { DINGI }]_{\mathrm{R}} \cdot \hat{\mathrm{U}}^{\mathrm{MES}}-a \check{S}^{\mathrm{d}}[\mathrm{Ma} a-a-l i-i a(?)$

$5^{\prime} \quad[\mathrm{x} \mathrm{x}(\mathrm{x})(-) \bar{s}] a^{?}-a-{ }^{-} r a^{\urcorner}(-)[$

$6^{\prime} \quad[\mathrm{xx}(\mathrm{x})] \mathrm{x}^{\mathrm{d}} \mathrm{x}[$

$7^{\prime} \quad[\mathrm{x} x(\mathrm{x}) p] e^{\prime}-e-\mathrm{x}[$

$8^{\prime} \quad[\mathrm{x} x(\mathrm{x})] \mathrm{x}-k u-\mathrm{x}[$

$9^{\prime} \quad[\mathrm{x} x(\mathrm{x})] \check{s} a-r a-\mathrm{x}[$

$10^{\prime} \quad[\mathrm{x} x(\mathrm{x})] \mathrm{x}$ kat-ta hu-u-i[a-an-zi (?)

$11^{\prime} \quad[\mathrm{x} \times(\mathrm{x})]-l i-i n d a-a-[$

$12^{\prime} \quad[\mathrm{x} \times(\mathrm{x})] \mathrm{x}$ ti-ia-zi nu $[\mathrm{x} \mathrm{x} \mathrm{x}] \times \mathrm{x} \times \mathrm{x}^{\ulcorner} \mathrm{S}^{7}-\mathrm{er}[$

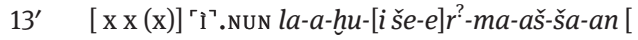

$14^{\prime} \quad[\mathrm{x} \times(\mathrm{x}) k i-i] s ̌$-ša-an me-m[a-i]

15' [ka-a-š $] a-w a-a t-t a$ KASKAL-a[n? kis-an h] $]$ - ${ }^{\prime} i t^{\urcorner}-t[i-i a-n u-u n(?)]$

16' [x x] X LÀL-ia pa-ap-p[ár-aš-h̆u-un] nu-wa-aš-š[a-an

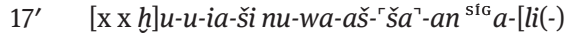

$18^{\prime} \quad[\mathrm{x} \mathrm{x} \mathrm{x}] \mathrm{x}$ nam-ma-kán MUNUS.LUGAL BI-IB-R $[U$

$19^{\prime} \quad[\mathrm{x} \times \mathrm{X}-a] n$ EGIR-pa $A-N A{ }^{\mathrm{d}} \mathrm{IM}{ }^{\mathrm{U}}{ }^{\mathrm{RU}}$

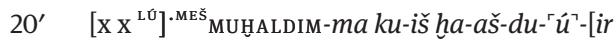

$21^{\prime} \quad[\mathrm{x} \mathrm{x}(\mathrm{x})] \mathrm{x}^{\text {LU.MEŠ MUHALDIM }}{ }^{\mathrm{d}} \mathrm{U}$.GUR 3 -šU X[

$22^{\prime} \quad[\mathrm{x} \mathrm{x}(\mathrm{x})]-a n$ h ha-aš-ši-i ti-an-zi n $[a$ -

23' [x x (x) d]a-a-i ḩa-a-aš-šu-uš-ma x[

$24^{\prime} \quad[\mathrm{x} x(\mathrm{x})] \mathrm{x}$ pé-di $d a-{ }^{\ulcorner} g a^{\top}-a n-z[i-p a-a n$

$25^{\prime} \quad[$

\section{Translation}

Obv.

$\begin{array}{lll}\mathrm{x}+1 & {[} & ] \\ 2^{\prime} & {[} & \text { ] and upon [ }[\end{array}$

$3^{\prime}$ [ ] a wicker table [

$4^{\prime} \quad$ a]nd the queen [

$5^{\prime} \quad$ ] ] liver[s

$6^{\prime}$ [ ] meat (det.) [

(What is left of lines obv. $7^{\prime}-12^{\prime}$ is too fragmentary to allow a translation)

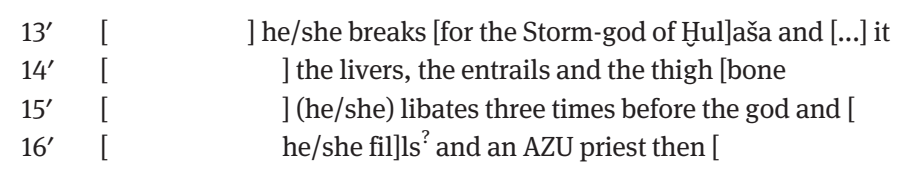

\begin{tabular}{|c|c|c|}
\hline $17^{\prime}$ & {[} & the Stor]m-god of Heaven a golden rhyton with wine [ \\
\hline $18^{\prime}$ & {[} & sil]ver (he/she) pours and [(he/she) gives (?) to dri]nk to the queen \\
\hline $19^{\prime}$ & {[} & go]ld with all the wine two times [ \\
\hline $20^{\prime}$ & {[} & o]n the wicker table he/she puts [ \\
\hline $21^{\prime}$ & {[} & ] (he/she) drinks (to) [M]aliya and the Sun-god, a[nd \\
\hline $22^{\prime}$ & {[} & th]en (he/she) puts it for the Storm-god [ \\
\hline $23^{\prime}$ & {[} & a cup be]arer? to the Storm-god of [ \\
\hline $24^{\prime}$ & {[} & ] (he) takes it [ba]ck and [ \\
\hline $25^{\prime}$ & {[} & ] and the queen [ \\
\hline
\end{tabular}


Rev.

$(\mathrm{x}+1-12$ ' fragmentary)

13' [ ] he/she pours butter and [upo]n? it [

$14^{\prime}$ [ ] he/she spea[ks as fol]lows:

15' [“Her]e a path for you [I have (?) dra]wn [in the following way:]

$16^{\prime}$ [ ] (and) honey [I have sprink]led, and [

$17^{\prime} \quad$ [ co]me!” And $a[l i]$ - wool [

$18^{\prime}$ [ ] ] and the queen a rhyto $[n$

19' [ ] then to the Storm-god o[f

$20^{\prime} \quad$ [ ] but [one of] the cooks, that [...] the bru[sh(wood)

$21^{\prime}$ [ ] ] the cooks [...] three times (to) ${ }^{\mathrm{d}} \mathrm{U} . \mathrm{GUR}$ [

$22^{\prime}$ [ ] they place it by the fireplace an[d

$23^{\prime}$ (he) takes [... ], the ashes however [

$24^{\prime}$ [ ] ] in the place [...] the flo[or

$25^{\prime} \quad[\ldots]$

The tablet preserves on the obverse the description of a series of libations, bread breakings and depositions on a wicker table, accompanied by the cooking of several sorts of meat, which strongly recalls the operations described in KBo 20.64 obv. Besides the food products used in the preparation of the path, a type of wool is mentioned in the invocation prayers performed in lines 15 'ff., as suggested by the presence of the determinative síg, followed by what seems to be a sign A. I find the integration ali- in KBo 30.119 rev. $17^{\prime}$ the most probable. The use of wool strings in the creation of ritual paths and gates intended to attract the deity is a well-known practice of Hittite ritual procedure. ${ }^{41}$ Ali-wool, in particular, is often used in purification rites, ${ }^{42}$ as a cathartic substance designed to absorb the impurity, or in the context of analogical magic. ${ }^{43}$

Both the Storm-god of Heaven and the Storm-god of Hulaša are mentioned in this context, together with a sun-deity, expressed by the logogram ${ }^{d_{U T U}}$, and the goddess Maliya. ${ }^{44}$ Probably connected to a river of the same name, as suggested by the (rare) presence of forms of the name preceded by the determinative íd, ${ }^{45}$ Maliya belongs to the most archaic stratum of Hittite religion, being documented already in the pantheon of Kaneš/Kültepe. ${ }^{46} \mathrm{~A}$ cult of this deity seems to survive, especially in Lycia, until classical times (Lebrun 1982: 124-125). Maliya is often associated, from the Old Hittite period, with the "male gods", generally in the syntactic construction ${ }^{\mathrm{d}}$ maliyaš DINGIR.LU ${ }^{\mathrm{MES}}$, "the male gods of $m$.". The presence of these deities in line obv. $4^{\prime}$ of our text makes the restoration of the name Maliya at the end of the line very probable. They would be, according to A. Archi, ${ }^{47}$ minor deities, a sort of genius loci closely connected with natural elements such as rivers and springs. The tendency to group smaller divinities around a god of the pantheon, would have its origin, according to Archi, in the Hurrian cultural milieu, and could have spread in Anatolia with the mediation of Kizzuwatna. Considering the toponyms mentioned in the text, the presence of the "male gods of Maliya" in it therefore seems perfectly consistent.

41 See Haas (2003: 622-690); Strauß (2006: 47-56).

42 Haas (2003: 680-684).

43 Cf. in particular Torri (2003: 139-140; 144-145).

44 On this deity see Lebrun (1982: 123-130); Frantz-Szabó (1988: 304-305). The attestations of the theonym are collected in van Gessel (1998: 296).

45 See Van Gessel (1998: 296).

46 The form Maliyanni, also attested in the plural (e.g. maliyanniaš), has been analyzed by Lebrun (1982: 123-124) as a name formed by the noun maliya and the appendix -anni, which would serve, according to the scholar, as a diminutive, as in the case of Ninatta-Ninattanni. However, the interpretation of -anni as a diminutive suffix is unfounded. Cf. CHD L-N 437. The reduplicated form Malimaliya is attested as the name of a mountain (e.g. KUB 7.24+, obv. i 5, CTH 506). The existence of a city Maliya, suggested by Laroche (1946-1947: 85), is not documented so far.

$47 \operatorname{Archi}(1979: 11)$. 
The logogram ${ }^{\mathrm{d}} \mathrm{U}$.GUR in line rev. $21^{\prime}$ is probably to be read as Zilipuri, as confirmed by parallel texts where the phonetic writing of the name in one passage corresponds to the logographic form in the other. ${ }^{48}$

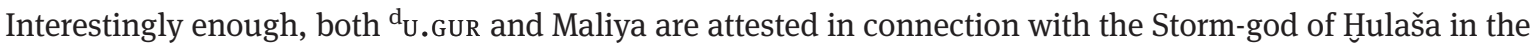
above-mentioned fragment of cult inventory KUB 44.1: the divine group could thus be seen as representing part of the pantheon of the city of Hulaša. The problem cannot be solved here, and certainly deserves further study.

The god Zilipuri, well attested from the Old Hittite period as a deity included in the circle of the goddess Lelwani, has a clear chthonic character. ${ }^{49}$ In the šalli ašeššar, the "great assembly" of the кI.LAm festival, Zilipuru ${ }^{50}$ occupies seventeenth place, preceded by Hanikkun and K[atahhi], and followed by Katimu and Halki. In the list of Hattian deities preserved in KBo 21.85 + KBo 8.109, ${ }^{51}$ a fragment belonging to the Festival of the Moon and the Thunder CTH 630, Zilipuri is preceded by Kataḩhi and followed by Walpišu (Ulipašu). In a later phase, Zilipuri is attested in association with chthonic deities such as DINGIR.MAH and ${ }^{\mathrm{d}}$ Gulš. From this period the use of the logogram seems to become prevalent.

In consideration of the probable South-Anatolian provenance of the text, a reading of U.GUR as Nergal, the Mesopotamian deity of the Underworld, would also be possible, although the strong connection of Zilipuri with the Fate deities, ${ }^{52}$ who are mentioned in another invocation ritual, KUB 15.31 (CTH 484), in a similar context, seems to point towards the first solution.

The presence of a deity somehow connected with the Netherworld strengthens the identification of the final section of the tablet with a cathartic rite, where the remains of the ritual material are burned (cf. hašši tiyanzi in obv. 22') and subsequently buried, thus reaching the Underworld. In this respect, the mention of the substantive haššs-, "ashes” (cf. HW² III Hु 388-391, HED 3: 210-212), in line rev. 23' seems to me particularly significant. In a rather obscure ceremony performed during the tenth day of the funerary ritual CTH $450,,^{53}$ the

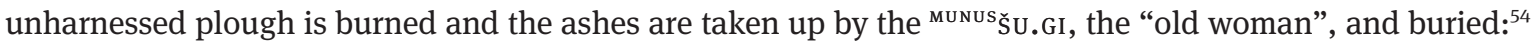
an operation which recalls, mutatis mutandis, the one that seems to be described in the last part of the invocation ritual analyzed here.

This is confirmed by the presence, a few lines earlier, of the quite rare substantive hašduir. The term, which is attested in association with plants and vegetal elements, is generally translated as "twigs", "brush (wood)" (cf. HW² III H 438; HED 3: 239; EDHIL 326-327), but it can also be used to indicate some kind of weed or the residual chaff which results from the plowing of the fields (thus Bawanypeck 2005: 67).

In ritual context this vegetal substance is often associated with the act of burning. The term is used in analogous context in two passages. In the first one, KBo 13.199, $7^{\prime}$ (CTH 500), a small fragment of a festival from Kizzuwatna found in area L/18, in the excavation dump of the House on the Slope, the $h$. is burned before being dumped: ${ }^{(7)} h a-a \check{s}$-du-ir-ma ar-ḩa wa-a[r-nu-an-zi na-at-kán] / ${ }^{(8)}$ ar-ḩa šu-uh-hna-an-zi, “ [they] $\mathrm{bu}[\mathrm{rn}]$ the $h$. [and] they dump [it]".

Similarly, in KUB 17.28 iv 44 (СTH 730), a Hattian-Hittite bilingual ritual for the Moon-god collected together with other rituals and conjurations on a Sammeltafel: ${ }^{55}{ }^{(44)} a$-aš-zi-ma-kán ku-it ha-aš-du-e-ir na-at arha wa-ar-nu-wa-an-zi, "they burn the brush that is left". Also in this case, the phrase seems to describe the last action of the rite, occurring immediately before a double paragraph line. Both fragments are unfortunately very badly preserved, and not much more can be said about the function of the substance in the ritual procedure.

48 Yoshida (1991: 59). On this deity see also Pecchioli Daddi (2004: 357-367).

49 See in particular Torri (1999); Otten (1950: 119-136).

50 Besides being attested with the ending $-i$, more frequent, the theonym is documented also with the endings $-u$ and $-a$. Cf. van Gessel (1998: 582).

51 Partially replicated in KBo 20.70 + KBo 21.88 obv. ii 1ff., whose pertinence to CTH 630 is possible but far from certain. Cf. also n. 18.

52 On the Fate deities and their circle, see now Archi (2013:1-26).

53 On which see Kassian / Korolëv / Sidel'tsev (2002).

54 KUB 39.14 i 12-15. Cf. also KUB 30.24a i 21-22. See Otten (1958:78).

55 On the composition of the Sammeltafel see Torri (2004: 129-141). 
The word hašduir in KBo 30.119 rev. 20' could refer to some vegetal remains of the ritual material, maybe used in the construction of the magic path, which are now burned and whose ashes are deposed in the ground. In light of this it is perhaps possible to understand the mentioning, in the parallel text KBo $20.64 \mathrm{rev}$. $5^{\prime}$, of the object called hahhal. The exact meaning of this term is disputed. Like the hašduir, it indicates some kind of wild vegetation, and it is generally translated as "brush", "bush", "undergrowth" (HW' III H 3-4; HED 3: 3). That the two terms are not equivalent is confirmed by the fact that both are attested in the same context in the ritual KUB $24.14 \mathrm{iff.}$ (CTH 397.A), in a list of vegetal elements which are mixed in order to form a compound used for magical/medical purposes. ${ }^{56}$

The hahhal is attested twice in the context of the preparation of the magic path, in the invocation KUB 15.34 i $43 \mathrm{ff}$. (CTH 483), directed to the "male gods of the cedar", hitt. DINGIR ${ }^{\text {MEŠ }}$ LƯ $^{\text {MEš GIŠ }}{ }_{\text {ERIN- }} a \check{s}:{ }^{(43)} n u-u s ̌-m a-$

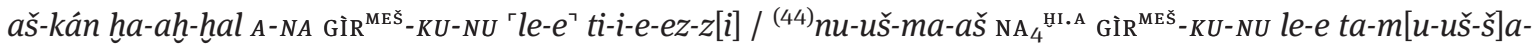
an-z[i], "The undergrowth shall not stand (against) your feet. The stones shall not press your feet". The same formula, with slightly different syntax, is repeated in the ritual for the Storm-god of Kuliwišna CTH 329, in lines KBo 15.32 iv $2 \mathrm{ff}$. and KBo 14.89+ i 4, where the undergrowth is conceived negatively, as a disturbing element which could interfere with the proceeding of the god along the path. As observed above, the presence of the substantive GİR in KBo 20.64 rev. $5^{\prime 57}$ must probably be understood in this context.

The final burning of these vegetal substances and the possible burial of the remaining ashes must be interpreted as symbolic practices with a cathartic meaning, and are clearly to be connected with the character of the invocation rite, which was probably conducted in order to appease an angry god, and call him back to bestow his favors upon the Land of Hatti. I find particularly interesting a passage of Anniwiyani's ritual CTH 393, whose main manuscript is preserved in the compilation tablet VBoT $24 .{ }^{58}$ Starting from rev. iii $4^{\prime}$, the mugawar-rite for ${ }^{\mathrm{d}_{\mathrm{KAL}}}$ of the kurša- bag is described. Among the ritual material prepared in order to attract the deity, in lines rev. iii 14-20, nine kinds of food, nine stones from a plowed field and the hašduir of a plowed field, are mentioned. The stones and the $h$. are placed on a hearth and burned. In the following

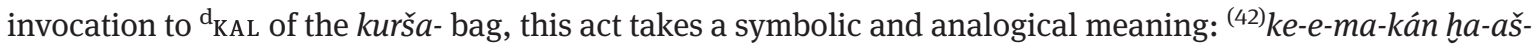

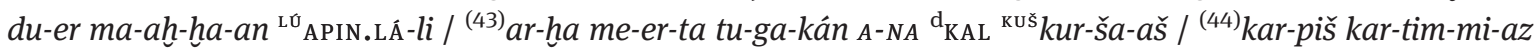
$\check{s} a$-a-u-wa-ar / ${ }^{(45)} a r$-h̆a QA-TAM-MA me-er-tu4, "as this hašduir is lost to the plower, so shall the anger, the rage and the resentment be lost to you, ${ }_{\mathrm{K}}^{\mathrm{KAL}}$ of the kurša-!"

Even if not explicitly indicated, the (probable) burning of the hašduir substance at the end of the invocation ritual described in KBo 30.119 should probably be understood in the same manner. The invocation rite, besides aiming at calling an angry god back to Hatti, must somehow dispose of the impurity caused by his absence. Many mugawar for a disappearing god are testimony to this practice. In the well-known Telipinu myth, for example, the "wrath, anger, sin and rage" of the god are sent to the Netherworld and locked in the palhi vessels. In the myth of the disappearing of the Storm-god of Heaven CTH 325, the goddess Hannahanna performs a magic ritual, described in the fragmentary tablet KUB 33.28, during which the god's rage is burned in an analogical procedure. The name of the second element of the analogy is unfortunately lost in break, but it is generally intended as a flammable substance such as straw ("paglia", cf. Pecchioli / Polvani 1990: 99), or kindling wood (Hoffner, Jr. 1990: 22). The disposal of the anger of Hannahanna is described in the same terms in KUB 33.45+ (// KUB 33.51), where the soul of the deity is compared to some kind of wood, "kindling" according to CHD L-N: 78b. As the wood burns up, the rage and the wrath of the goddess shall burn up. In the following passage, an analogical rite is carried out by the goddess Hapantali, who brings karšani-wood from the mountains and sets fire to it in the hearth.

The rite described in the final section of the two tablets under analysis, if we assume that they both describe an analogous ritual invocation, seems thus to combine the burning-rite, well documented in Hittite mugawar invocations, and the burial which is typical of purification rites.

56 See Zeilfelder (2000: 500-501).

57 See the text edition above.

58 See Bawanypeck (2005: 51-70); Peled (2010: 69-81). 


\section{The Cultic Personnel}

Before concluding the analysis of the two fragments, a few considerations on the cultic personnel involved in the rites are in order.

Whereas in KBo 20.64 not a single name of cult functionaries is preserved, in KBo 30.119 the queen, in lines obv. $4^{\prime}, 18^{\prime}, 25^{\prime}$, and an Azu-priest, in line obv. $16^{\prime}$, are mentioned. Both of them play an active role in the rite. The queen, in particular, performs a libation for the Storm-god of Heaven in the obverse of the tablet, and she is mentioned together with a вIBRU vessel immediately after the invocation prayer on the reverse. This is in contrast with the total absence of references to the king or the queen in KBo 20.64, and further corroborates the idea that we are dealing with two distinct rituals, albeit ones that were very close in structure and content. The queen is to my knowledge not attested in Hittite invocation ceremonies, while she is documented in other magic rituals, e.g. in the taknaz da- ritual CTH 448.2.2.1,59 or in CTH 494, performed for the goddess NIN.GAL. Interestingly, she is present as executor in some ritual texts connected with the cult in the city of Kuliwišna, currently collected under CTH 330. One example is KBo $56.1,{ }^{60}$ which runs parallel to KUB $43.56+$ KBo $51.189+$ KBo 52.8 obv. ii $29^{\prime}-$ rev. iii $28^{\prime}$, a Sammeltafel where at least two independent rituals related to Kuliwišna are collected. ${ }^{6}$ Similarly, the queen plays an active role, together with the king, in two rites connected to this city, probably part of two compilatory tablets represented by KBo 25.158 and KBo 15.36 .$+^{62}$ The pertinence of these rites to the mugawar for the Storm-god of Kuliwišna is rejected by J. Glocker (Glocker 1997: 10-12) on account of the presence of the royal couple in an active role, a role never attested elsewhere in the tablets of the corpus or in other versions of the ritual, where only the 'lord of the House', ${ }^{\mathrm{L}}{ }_{\mathrm{EN}}^{\mathrm{LN}}$ $\hat{\mathrm{E}}^{I I M}$ is documented as primary ritual practitioner. The exact placement of these texts, and their relationship with the invocation ritual for the Storm-god of Kuliwišna, need to be further investigated.

While a role by the queen in invocation rituals can therefore not be ascertained with certainty, the ${ }^{\mathrm{LU}} \mathrm{AZU}-$ priest is well attested as performer of this type of ceremonies. He is the main actor in KUB 15.31 (CTH 484) and KUB 15.34 (CTH 483), two texts that, as already pointed out by V. Haas and G. Wilhelm (Haas / Wilhelm 1974: 180-181), must be considered as closely related to each other, as well as in KBo 24.69 (CTH 716), an invocation ritual for IŠTAR of Ninive ${ }^{63}$. As correctly underlined by S. Görke (Görke 2010: 252-253), this cult functionary seems not to be connected with the cult of a particular deity or a particular divine group.

Quite interestingly, however, in KBo 10.45 (CTH 446), the well-known ritual for the purification of the

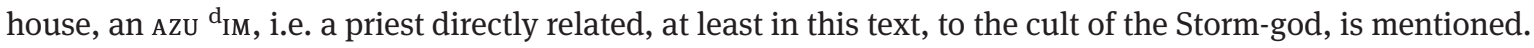
In view of this, and in view of the fact that the AzU-priest is the main practitioner in the festival for the Stormgod of Kuliwišna CTH 330 and in the ritual of Pilliya CTH 475 for the instatement of the cult of the Storm-god of Kizzuwatna, the presence of this cult functionary in the ritual under analysis, given its character, and the role played in it by weather deities such as the Storm-god of Heaven and the Storm-god of Hulaša, seems to me to be perfectly justified. Due to the conditions of the tablet, it is impossible to determine whether he is to be considered the main practitioner of the rite, as seems likely, or not.

The association between the queen and the AzU-priest documented in KBo 30.119 can be found in other cultic ceremonies, such as the celebrations for IŠTAR of Hattarina performed during the AN.TAH.šUm festival (CTH 615), in the festival of Huwaššanna CTH 694, and in the cult of IšTAR (CTH 713 and 714).

59 See S. Görke (ed.), hethiter.net/: CTH 448.2.2.1 (INTR 2012-01-25). On the taknaz da- rituals see Görke (2010: 174-179), with further literature.

60 I thank Giulia Torri for bringing this fragment to my attention.

61 See Trémouille (2002: 360-361).

62 Published in Glocker (1997: 98-107).

63 See F. Fuscagni (ed.), hethiter.net/: CTH 716.2 (INTR 2011-01-21). 


\section{The Colophon}

Of the colophon of KBo 20.64, separated from the rest of the column by a double paragraph divider, only four signs are preserved. The integration [... t]ethešnaš is in my opinion the only one possible. The mention of thunder, hitt. tetheššar, in a genitive form dependent on another substantive, lost in the break, is quite difficult to explain, and it is probably the reason for the inclusion of the text in CTH 631, a corpus of documents related to thunder which, however, are clearly different in character from the ones we are dealing with here.

In consideration of the points mentioned above, this reading seems to confirm the identification of the document as an invocation ritual intended to appease an angry Storm-god, like the mugawar CTH 324 for the disappearance of Telipinu. Thunder is often perceived in Hittite religious thought as a sign of divine rage: Telipinu himself, in KUB 17.10+ ii 34, a tablet belonging to the same composition, is described as follows: lee-la-ni-ia-an-za ú-it ú-wa-an-ti-wa-an-ta-az ti-it-hi-iš-ki-it-ta, "(he) came enraged and thundered with a light". ${ }^{64}$ This seems to me further confirmed by the description, in KBo 20.64 obv. $3^{\prime}-8^{\prime}$, of rites and offerings before a window, which strongly recalls the rites carried out during some thunder festivals. ${ }^{65}$

One would expect the title of the composition or a more general indication of the content of the tablet to be present in the colophon. Two explanations for the presence in this place of the substantive tetheššar are therefore possible in my opinion. We could think that the invocation ritual whose celebration seems to be described in the two fragments was addressed to a particular hypostasis of the Storm-god, the Storm-god of

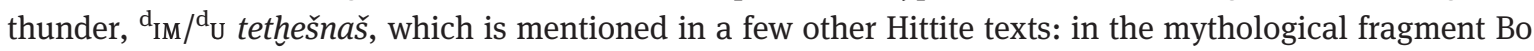
2567 (CTH 342) i 3', as well as in the Prayer of Muwatalli II to the assembly of gods KUB 6.45 i 49 (CTH 381), where the god is mentioned among the deities of Katapa.${ }^{66}$ In this case the genitive form would be dependent on a logogram ${ }^{\mathrm{d}} \mathrm{U} / \mathrm{d}_{\mathrm{IM}}$ to be integrated in the break.

Among the Hittite tablet catalogues published by P. Dardano, ${ }^{67} \mathrm{I}$ find some interesting mentions of invocations rites directed to local forms or particular hypostases of the Storm-god, often collected with other rites in Sammeltafeln.

In the Late Hittite tablet KBo 31.27+ (СТH 277) several invocation rites are recorded. Among these the following ones may be mentioned:

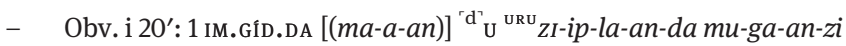

"One long tablet: [When] they incite ${ }^{68}$ the Storm-god of Zippalanda"

- Obv. ii 2': [... $\left.{ }^{\mathrm{d}} \mathrm{IM} a-r i-i\right] a-[a] t-t a l-l i$ ma-ah-ha-an 'mu-ga- $a^{\urcorner}-[m i$

"When [I] incite the [Storm-god] of the [moun]tain"

In KBo 31.6 (CTH 277), an invocation for the "Storm-god of the rich (man)"”o is mentioned:

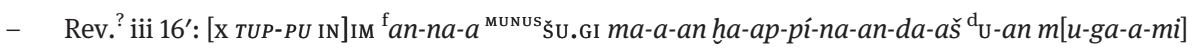
"[x tablet of the wo]rd of Anna, the old woman: when [I inci]te the Storm-god of the rich (man)"

Similarly, in KUB 30.56 (CTH 279):

- $\quad$ Rev. iii 19: [ma]-a-an-za LUGAL-uš ${ }^{\mathrm{d}} \mathrm{U}$ KARAŠ DUั- $z i(. .$.

"[Wh]en the king celebrates the Storm-god of the camp (...)"

64 Pecchioli Daddi / Polvani (1990: 81) translate: “Telipinu, infuriato, venne lampeggiando e tuonando”.

65 See the discussion on KBo 20.64 above.

66 Cf. Singer (1996: 11).

67 Dardano (2006).

68 For the translation of $m \bar{u} g \bar{a}(i)$ - as "rouse”, “incite”, see Melchert (2010: 207-215), who rejects the interpretation of the verb as a verbum dicendi.

69 On the Luwian epithet ariyattalla/i-, derivative from *ariyatt(i)-, “elevation, mountain”, see CLL 27; KZ 93.

70 On which see Dardano (2006: 186), with further references. 
The performing of mugawar rites directed to hypostases of the Storm-god were thus a recurrent feature in Hittite ritual tradition. Accordingly, a restoration of the colophon in KBo 20.64 as follows could be plausible:

[mugawar/sískuR ${ }^{\mathrm{d}} \mathrm{U} t$ ]ethešnaš

[mugawar/ritual of the Storm-god] of thunder

In this case the text should be listed under the entry 332 of the Catalogue des textes hittites, among the fragments of mugawar rituals directed to the Storm-god.

Alternatively, we can imagine that the mention of thunder has to be seen as referring not to the particular storm-god being invoked, but to the typology of the composition.

Thus:

$[(\mathrm{x})$ DUB/TUPPU t]ethešnaš [

"[Tablet (x)] of the thunder [...]"

Or:

[sískur/mugawar t]ethešnaš [

"[Ritual/mugawar] of the thunder [...]"

Considering that the expression Duв tethešnaš seems to be used by Hittite scribes to indicate the Sammeltafeln where several festivals related to thunder are collected, e.g. in the colophon of the old Hittite tablet KBo 17.74 +, or in KBo 17.75 (MS), ${ }^{71}$ I find the integration mugawar/sískUR more convincing. In this case, a collocation of both KBo 20.64 and KBo 30.119 under CTH 459 (Fragments of mugawar) seems preferable.

Hittite documentation provides another example of a rite directly related to the atmospheric phenomenon of thunder which has both the structure and the vocabulary of a magical ritual. This involves the rite carried out by the man of the Storm-god "when the Storm-god thunders frightfully", which constitutes the frame of the bilingual myth generally known as the myth of "the Moon that fell from Heaven" (CTH 727). ${ }^{72}$ The ritual is preserved in Middle (MS) and Late (NS) Hittite manuscripts, but certainly reflects an Old Hittite tradition, an ideological and religious substrate where the "festivals of the thunder" collected in CTH 631 also have their roots. The rite does not contain, as far as it is possible to understand from the preserved parts, an invocation to the Storm-god, whose appeasement is obtained through offerings, the performing of libations and bread breakings, and, most important, by the symbolic drinking of the thunders, the lightnings, the clouds and the rains of the Storm-god, followed by the drinking of the fears and the anxieties of the enraged deity.

These rites constitute, in my opinion, an example of a cult praxis which probably was more frequent than the textual evidence at our disposal seems to indicate. Both the festivals and the rituals connected with thunder reflect a theological concept which perceives the phenomenon as an ominous sign and a signal of the god's rage, but they respond to different needs. The thunder festivals were performed on a regular basis, and had a clear seasonal character, being celebrated on the occasion of the first spring thunderstorms. ${ }^{73}$ Rituals such as KBo 20.64 and its parallel KBo 30.119, by contrast, were conceived as a response to critical situations, and, as such, could include invocations to the gods whose anger had to be appeased in order to resolve the crisis. In this sense, the two fragments here published constitute an important record of an otherwise poorly attested Hittite religious practice.

71 Both colophons are published in Barsacchi $(2014: 103,177)$.

72 See the most recent edition by Schuster (2002: 335-641). Cf. also Pecchioli Daddi / Polvani (1990: 109-114); Hoffner Jr. (1998: 33-35).

73 As evident from sources such as the oracular reports CTH 563 and CTH 564, where the thunder festival and the festival of the year are mentioned as the regular ceremonies, $\mathrm{EZEN}_{4}{ }^{\mathrm{MES}} \mathrm{SAG}$.Uš, the king has to perform at the turn of the year. This must be located at the beginning of the spring season according to the text KUB 38.32 rev. iv 13 (CTH 508). 


\section{References}

Archi, A. (1979): Associations des divinités hourrites, UF 11, 7-12.

Archi, A. (2013): The Anatolian Fate Goddesses and their Different Traditions. In: E. Cancik-Kirschbaum / J. Klinger / G.G.W. Müller, Diversity and Standardization: Perspectives on Social and Political Norms in the Ancient Near East, Berlin, 1-26.

Archi, A. (forthcoming): How a God of Nature Became a Tutelary God. In: Proceedings of the $9^{\text {th }}$ Congress of Hittitology, Çorum.

Barsacchi, F.G. (2014): Le cerimonie ittite del tuono: Edizione critica di CTH 630 e 631, PhD Dissertation, Università degli Studi di Firenze.

Bawanypeck, D. (2005): Die Rituale der Auguren (THeth 25), Heidelberg.

Collins, B.J. (2002): Necromancy, Fertility and the Dark Earth: The Use of Ritual Pits in Hittite Cult. In: P. Mirecki / M. Meyer (ed.),

Magic and Ritual in the Ancient World (Religions in the Graeco-Roman World 141), Leiden - Boston - Köln, 224-241.

Dardano, P. (2006): Die hethitischen Tontafelkataloge aus Hattuša (CTH 276-282) (StBoT 47), Wiesbaden.

Forlanini, M. (1988): La regione del Tauro nei testi ittiti, V0 7, 129-169.

Frantz-Szábo, G. (1988): Malija(nni), Malimalija, RIA 7, 304-305.

Freu, J. (1992): Les guerres syriennes de Suppiluliuma et la fin de l'ère amarnienne, Hethitica 11, 39-101.

Friedrich, J. (1952-1954): Hethitisches Wörterbuch. Kurzgefasste kritische Sammlung der Deutungen hethitischer Wörter. 1. -4 . Lieferung, Heidelberg.

Fuscagni, F. (2007): Una nuova interpretazione del rituale CTH 423 alla luce di tre nuovi duplicati, Kaskal 4, 181-219.

Glocker, J. (1997): Das Ritual für den Wettergott von Kuliwišna: Textzeugnisse eines lokalen Kultfestes im Anatolien der Hethiterzeit (Eothen 6), Florence.

Goetze, A. (1940): Kizzuwatna and the Problem of Hittite Geography (YOS Researches 22), New Haven.

Görke, S. (2010): Das Ritual der Aštu (CTH 490): Rekonstruktion und Tradition eines hurritisch-hethitischen Rituals aus BoğazköyHattuša (CHANE 40), Leiden - Boston.

Groddek, D. (2002): Hethitische Texte in Transkription: KBo 30 (DBH 2), Dresden.

Güterbock, H.G. (1952): The Song of Ullikummi, JCS 6, 8-42.

Güterbock, H.G. (1957): Rev. of Friedrich 1952-1954, Oriens 10, 350-362.

Haas, V. (2003): Materia Magica et Medica Hethitica: Ein Beitrag zur Heilkunde im Alten Orient, Berlin - New York.

Haas, V. / G. Wilhelm (1974): Hurritische und luwische Riten aus Kizzuwatna (AOATS 3 = Hurritologische Studien 1), Kevelaer Neukirchen-Vluyn.

Hagenbuchner-Dresel, A. (2002): Massangaben bei hethitischen Backwaren (DBH 1), Dresden.

Hawkins, J.D. (2005): Commentaries on the Readings; Commentary on the Sign List. In: S. Herbordt, Die Prinzen- und Beamtensiegel der hethitischen Grossreichszeit auf Tonbullen aus dem Nişantepe-Archiv in Hattusa - mit Kommentaren zu den Siegelinschriften und Hieroglyphen von J. David Hawkins (BoHa 19), Mainz, 248-313; 426-436.

Hoffner Jr., H.A. (1967): Second Millennium Antecedents to the Hebrew 'ôb, JBL 86, 385-401.

Hoffner Jr., H.A. (1990): Hittite Myths (SBL WAW 2), Atlanta (Ga.).

Hoffner Jr., H.A. / C. Melchert (2008): A Grammar of the Hittite Language (LANE 1), Winona Lake, Indiana.

Hutter, M. (2013): Concepts of Purity in Anatolian Religion. In: Ch. Frevel / Ch. Nihan (ed.), Purity and the Forming of Religious Traditions in the Ancient Mediterranean World and Ancient Judaism (Dynamics in the History of Religions 3), Leiden - Boston, 159-174.

Jakob-Rost, L. (1972): Das Ritual der Malli aus Arzawa gegen Behexung (KUB XXIV 9+) (THeth 2), Heidelberg.

Kassian, A.S. / A. Korolëv / A. Sidel’tsev (2002): Hittite Funerary Ritual: šalliš waštaiš (AOAT 288), Münster.

Klinger, J. (1996): Untersuchungen zur Rekonstruktion der hattischen Kultschicht (StBoT 37), Wiesbaden.

Laroche, E. (1946-1947): Recherches sur les noms des dieux hittites, RHA 7/46, 7-139.

Laroche, E. (1973): Études de linguistique anatolienne, RHA 31, 83-99.

Laroche, E. (1980-1983): Lamma/Lamassu. C. Anatolien, RIA 6, 455-459.

Lebrun, R. (1982): Maliya, une divinité anatolienne mal connue. In: J. Quaegebeur (ed.), Studia Paulo Naster oblata. Vol. II: Orientalia Antiqua (OLA 13), Leuven, 123-130.

Melchert, C. (2010): On Hittite mūgā(i). In: R. Francia / G. Torri (ed.), Studi di Ittitologia in onore di Alfonso Archi (Or. 79), Rome, 207-215.

Miller, J. (2004): Studies in the Origins, Development and Interpretation of the Kizzuwatna Rituals (StBoT 46), Wiesbaden.

Mouton, A. (2004): Anatomie animale: Le festin carné des dieux d'après les textes hittites I. Les membres antérieurs, Colloquium Anatolicum 3, 67-92.

Mouton, A. (2012): Le rituel d’Allī d'Arzawa contre un ensorcellement (CTH 402): Texte et contexte, Colloquium Anatolicum 11, 247-266.

Mouton, A. (2013): Le rituel d’Alli d’Arzawa contre un ensorcellement (CTH 402): Une nouvelle édition. In: B.J. Collins / P. Michalowski (ed.), Beyond Hatti: A Tribute to Gary Beckman, Atlanta, 195-230.

Neu, E. (1970): Ein althethitisches Gewitterritual (StBot 12), Wiesbaden.

Otten, H. (1950): Die Gottheit Lelvani der Bogazköy-Texte, JCS 4, 119-136.

Otten, H. (1958): Hethitische Totenrituale, Berlin. 


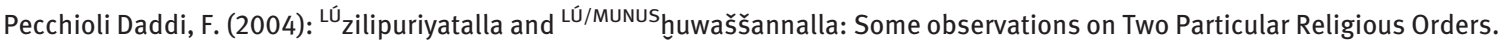
In: M. Hutter / S. Hutter-Braunsar (ed.), Offizielle Religion, lokale Kulte und individuelle Religiosität: Akten des religionsgeschichtlichen Symposiums "Kleinasien und angrenzende Gebiete vom Beginn des 2. bis zur Mitte des 1. Jahrtausends v. Chr.” (Bonn, 20.-22. Feburar 2003) (AOAT 318), Münster, 357-367.

Pecchioli Daddi, F. / A. Polvani (1990): La mitologia ittita (TVAO 4 = Letterature dell'Asia Minore 1), Brescia.

Peled, I. (2010): Expelling the Demon of Effeminacy: Anniwiyani’s Ritual and the Question of Homosexuality in Hittite Thought, JANER 10, 69-81.

Polvani, A. (2005): The deity IMIN.IMIN.BI in Hittite Texts, Or. 74, 181-194.

Popko, M. (1991): Weitere Fragmente zu CTH 418, AoF 18, 44-53.

Rüster, C. / G. Wilhelm (2012): Landschenkungsurkunden hethitischer Könige (StBoT Beih. 4), Wiesbaden.

Schuster, H.-S. (2002): Die hattisch-hethitischen Bilinguen. Bd. 2: Textbearbeitungen Teil 2 und 3 (DMOA 17/2), Leiden - Boston Köln.

Singer, I. (1996): Muwatalli's Prayer to the Assembly of Gods through the Storm-God of Lightning (CTH 381), Atlanta (Ga.).

Starke, F. (1985): Die keilschrift-luwischen Texte in Umschrift (StBoT 30), Wiesbaden.

Strauß, R. (2006): Reinigungsrituale aus Kizzuwatna: Ein Beitrag zur Erforschung hethitischer Ritualstradition und Kulturgeschichte, Berlin - New York.

Torri, G. (1999): Lelwani: Il culto di una dea ittita (VO Quad. 2), Rome.

Torri, G. (2003): La similitudine nella magia analogica ittita (Studia Asiana 2), Rome.

Torri, G. (2004): A Hittite Magical Ritual to Be Performed in an Emergency, JANER 4, 129-141.

Trémouille, M.C. (2002): Une cérémonie pour Huwaššanna à Kuliwišna. In: P. Taracha (ed.), Silva Anatolica: Anatolian Studies Presented to Maciej Popko on the Occasion of His 65th Birthday, Warsaw, 351-369.

Ünal, A. (1998): Hittite and Hurrian Cuneiform Tablets from Ortaköy (Çorum), Central Turkey: With two Excursuses on the "Man of the Storm God" and a Full Edition of BBo 23.27, Istanbul.

van Gessel, B.H.L. (1998): Onomasticon of the Hittite Pantheon 1-2 (HdOr. 33), Leiden - New York - Köln.

Weeden, M. (2011): Hittite Logograms and Hittite Scholarship (StBoT 54), Wiesbaden.

Wilhelm, G. (1995): Zur Ritual- und Redaktionsgeschichte des althethitischen Gewitterrituals CTH 631.1. In: O. Carruba / M. Giorgieri / C. Mora (ed.), Atti del II Congresso Internazionale di Hittitologia, Pavia 28 giugno-2 luglio 1993 (StMed 9), Pavia, 381-388.

Wright, D.P. (1987): The Disposal of Impurity: Elimination Rites in the Bible and in Hittite and Mesopotamian Literature, Atlanta (Ga.).

Yoshida, D. (1991): Ein hethitisches Ritual gegen Behexung (KUB XXIV 12) und der Gott Zilipuri/Zalipura. In: T. Mikasa (ed.), Essays on Ancient Anatolian and Syrian Studies in the 2nd and 1st Millennium B.C. (BMECCJ 4), Wiesbaden, 45-61.

Zeilfelder, S. (2000): Heth. tuhbueššar und der Thymian. In: M. Ofitsch / C. Zinko (ed.), 125 Jahre Indogermanistik in Graz: Festband anlässlich des 125jährigen Bestehens der Forschungseinrichtung “Indogermanistik” an der Karl-Franzens-Universität Graz, Graz, 497-508.

Note: I am deeply grateful to Prof. Giulia Torri for reading a previous draft of this paper and for her precious comments and suggestions. The abbreviations follow those used in: Güterbock, H.G. $\dagger$ / H.A. Hoffner Jr. $\dagger$ / Th.P.J. van den Hout (ed.), The Hittite Dictionary of the Oriental Institute of the University of Chicago (CHD), Chicago, 1989-. 